ELORE (ISSN 1456-3010), vol. $14-1 / 2007$.

Julkaisija: Suomen Kansantietouden Tutkijain Seura ry.

[http://www.elore.fi/arkisto/1_07/asp1_07.pdf]

\title{
KIRJA-ARVIO:
}

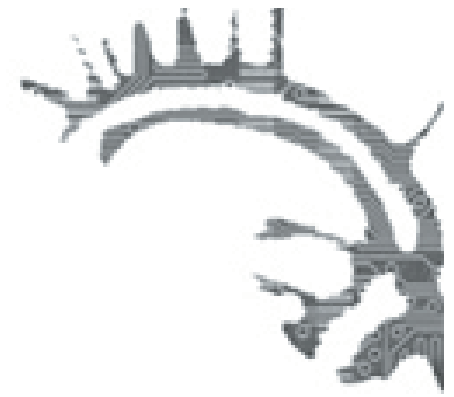

\section{ESIMODERNIN YKSILÖN RAKENTUMINEN SUOMALAISESSA TAIKAPERINTEESSÄ}

Stark, Laura 2006: The Magical Self: Body, Society and the Supernatural in Early Modern Rural Finland. Folklore Fellows Communications 290. Helsinki: Academia Scientiarum Fennica. 521 sivua.

\section{Camilla Asplund Ingemark}

Lauran Starkin uusin kirja on hyvä esimerkki siitä, kuinka jatkuvasti kehittyvä ja laajentuva tutkimustyö, joka on keskitetty aika laajalle mutta silti hyvin tarkennetulle tutkimusalueelle, voi avata uusia näkökulmia "vanhaan" aiheeseen. Väitöskirjassaan Magic, Body and Social Order (1998) Stark tutki naisten maagisia riittejä Suomessa 1800ja 1900-luvuilla, ja teoksessa Peasants, Pilgrims, and Sacred Promises (2002) hän kehitteli analyysia muun muassa kansanomaisen ja ortodoksisen uskon pyhyyskäsityksistä. The Magical Self on tutkimus yksilön ja yksilöllisyyden rakentumisesta suomalaisessa taikaperinteessä. Tällä kertaa huomion keskipisteenä ovat kertomukset taikuudesta eivätkä maagiset rituaalit sinänsä, mikä johtaa erilaisiin pohdintoihin kuin yllämainituissa teoksissa.

\section{LÄHTÖKOHDAT JA NÄKÖKULMAT}

Miten yksilön kokemuksista kerrotaan, ja miten taikuus ja noituus kytkeytyvät tähän asiaan, ovat kirjan pääkysymykset. Aineistona on yli 1750 kertomusta sekä yli 5000 loitsua, joista 450 tutkitaan tarkemmin. Jo tässä vaiheessa on kenties syytä huomauttaa, että kirjoittaja käsittelee nykyistä erotusta faktan ja fiktion välillä hyvin järkevästi sanoessaan, että esimodernissa yhteisössä sekä oma kokemus, eli memoraatti, että stereotyyppinen uskomustarina auttoivat henkilöä omien elämysten tulkinnassa ja yrityksessä antaa niille kulttuurisesti ymmärrettävä kerronnallinen muoto. Ymmär- 


\section{ESIMODERNIN YKSILÖN RAKENTUMINEN SUOMALAISESSA TAIKAPERINTEESSÄ}

rettävyys oli myös tärkeämpää kuin "totuudenmukaisuus" yksilön subjektiuden rakentamisessa kerronnassa.

Starkin tulkinta perustuu ainakin kahteen perusolettamukseen: ensiksi, magian käyttö esimodernissa Suomessa ei ollut antisosiaalista toimintaa vaan keino ylläpitää olemassa olevia mutta vaarantuneita sosiaalisia suhteita, ja toiseksi, magia ei vaarantanut vaan edisti käyttäjän yksilöllisen henkilön muodostumista, koska se antoi yksilöllisen tilan yhteisössä, jossa sellaista ei juuri ollut nykyaikaisessa mielessä. Tämän johdosta kertomukset taikuudesta keskittyvät magian käyttöön eräänlaisena vastarinnan strategiana ulkopuolisen uhan torjumiseen, etenkin jos tämä uhka olisi voinut vähentää henkilön toimintakelpoisuutta yhteisössä. Stark korostaa itsenäisen toiminnan merkitystä esimodernissa yhteiskunnassa. Sen tärkeys näkyy hänen mukaansa koko taikaperinteessä. Itsenäisen toiminnan ja sen kautta sosiaalisen aseman suojelu on tässä kirjassa taikuuden ja noituuden raison-d'être, myös sen takia, että esimodernilla yksilöllä useimmissa tapauksissa oli vain yksi sosiaalinen verkosto, johon hänen täytyi tukeutua. Eristäminen tästä verkostosta, mistä syystä tahansa, oli suuri onnettomuus. Tilanteet, joissa henkilöt tunsivat itsensä ja sosiaalisen asemansa uhanalaisiksi, vaihtelivat: Stark käsittelee kateellisten naapurien, sairauden, metsänpeiton, papin, käräjätuomarin ja nuorisoryhmän ongelmallista valtaa yksilön näkökulmasta.

\section{YKSILÖ, RUUMIILLISUUS JA TOIMINTA}

Oman identiteetin luominen tapahtui ensinnäkin identifioitumalla kotitalouteen, joka miellettiin vaarallisen, pahansuovan ulkomaailman vastapuoleksi. Saman ovat todenneet muutkin suomalaiset tutkijat, kuten Lotte Tarkka. Kotitalouden ja oman kehon välillä oli jonkinlainen metonyyminen vastaavuus; kummankin rajoja uhkasivat vieraiden voimien ja ihmisten hyökkäykset. Yksilöllisen kehon kohdalla pelko ulkopuolisesta hyökkäyksestä perustui avoimen kehon skeemaan, ruumiillisen esityksen tiedostamattomaan, kulttuurisesti jäsentyneeseen tyyliin, jonka mukaan keho avautui ympäristöön vaarallisilla tavoilla. Näissä tilanteissa toisen ihmisen tahto tai dynamistinen voima voi tunkeutua yksilön kehoon ja hän sairastui. Stark erottelee neljä tunkeutumismekanismia: toisen henkilön, etenkin hierarkkisesti ylemmän yksilön, raivo voi rikkoa alemman henkilön ruumiilliset rajat ja aiheuttaa melkoista vahinkoa. Äkillinen säikähdys miellettiin kehon rajojen avautumisena ja vieraan voiman astumisena kehoon, samoin kompastuminen. Pelkkä ajatus tartunnan mahdollisuudesta herkisti ihmisen tartunnalle, koska toimintakelpoisuus heikentyi ja sen myötä mahdollisuus hallita ympäristöä.

Oman tutkimukseni kannalta keskustelu metsänpeitosta oli erityisesti kiinnostava varsinkin sen takia, että Stark analysoi metsänpeittokertomuksia sosiaalisesta näkökulmasta. Se antaa erilaisia vivahteita tulkintaan kuin omani, jonka painopiste on uskonnollisten käsitysten vaikutus ihmisen minäkuvaan suomenruotsalaisessa metsänpeittoperinteessä. Stark osoittaa, että metsänpeiton uhriksi joutuivat etenkin nuoret naiset ja miehet, joiden asema sosiaalisessa hierarkiassa oli heikko ja joilla oli heikompi 


\section{Camilla Asplund Ingemark}

kuva itsestään itsenäisinä toimijoina. Siksi he kokivat metsään eksymisen vievän heiltä yksilöllisyyden, joka oli vahvasti sidoksissa paikallisyhteisöön. Kertomuksissa metsä edustaa moniulotteista tilaa, jonka määrittää sen toiseus "normaaleista", yhteisön rajojen sisäpuolelle sijoittuneista tiloista. Stark käyttää Michel Foucaultin esittelemää termiä heterotopia tämän toiseuden tilan kuvaamisessa. Juuri toiseuden merkitys termin alkuperäisessä määrittelyssä Foucaultin ajattelussa tekee siitä tarkoituksenmukaisen käsitteen tuonpuoleisen metsän erikoispiirteiden ymmärtämisessä. Näkemys metsästä heterotopiana selittää myös yksilön kokemat vaikeudet sopeutumisessa takaisin yhteisöön: toiseuden piirittämänä ja aktiivisen subjektiuden menettäneenä metsänpeiton uhri jopa pelkäsi etsintäpartioiden lähestymistä. Oli siis etsijöiden, ja varsinkin luonnokkaan tietäjän, tehtävä rikkoa metsän valta.

Tietäjä nostetaan esiin esimodernin yhteisön ihanneyksilönä. Hänellä oli sitä, mitä nykyisin kutsutaan "oikeaksi asenteeksi": hän suuttui helposti, oli aina valmis puolustamaan toimintakelpoisuuttaan raivokohtauksen ja nopean vastaiskun avulla, ja hänellä oli karkea luonto. Äkkipikainen luonne ja kova luonto olivat yhteenkietoutuneet monin tavoin; tietäjän luonne oli välttämätön hänen ammatissaan, ja yliluonnollinen voima, luonto, nostettiin suuttumisen ja raivon avulla. Stark havainnollistaa analyysissaan, että esimodernin yksilön raivo ei ollut pelkkä tunne vaan kulttuurinen esitys, jolla pystyttiin viestittämään toimintakelpoisuus ja yhteisöllinen asema suhteessa toisiin. Metsänpeiton uhreilla ei ollut tällaista asennetta heikon sosiaalisen asemansa vuoksi.

Kristilliset uskomukset tarjosivat kilpailevia ihanteita nöyrästä ja anteeksiantavasta ihmisestä, ja jossain määrin nämä ihanteet tulevat esiin kertomuksissa, enimmäkseen noituuden uhrin kostosta luopumisen yhteydessä. Monet omaksuivat kuitenkin aggressiivisen, rajojaan suojelevan yksilöllisyyden ihanteen ainakin niissä tilanteissa, joissa henkilön koko tulevaisuus yhteisön kunnioitettuna jäsenenä oli vaarassa. Tällaisia tilanteita olivat esimerkiksi julkisen nöyryyttämisen rituaalit, jotka suoritettiin kirkossa jumalanpalveluksen aikana tai papin käskystä, käräjät, joissa tuomio rikokseen syyllistymisestä merkitsi kunnian menetystä, ja tanssit, joissa henkilön naimakelpoisuus punnittiin. Sosiaalisen kilpailukyvyn turvaamiseksi yksilö ryhtyi magiaan kyetäkseen vastustamaan muiden häpäisemisyrityksiä. Modernista näkökulmasta oudoimmalta tuntuu magian käyttö oikeudessa, koska käyttäjän mielessä ei ollut kysymys syyllisyydestä tai edes huonosta omastatunnosta vaan kilpailusta, joka täytyi voittaa. Kiintoisaa tässä yhteydessä on, että henkilöt, jotka ovat menettäneet toimintakelpoisuutensa ja sosiaalisen asemansa, eivät saa kertoa tarinaansa kansanperinteessä. He ovat mykkiä, ja ainoa mahdollisuus vastarintaan on ruumiillisen protestin ja väkivallan kautta. Diskurssin poissulkeutumismekanismit, kuten Foucault asian ilmaisee, ovat vahvat.

\section{ESIMODERNISTA MODERNIIN YKSILÖÖN}

Tutkimuksen ehkä merkittävin tulos on näkemys modernisaation vaikutuksesta esimoderniin avoimen kehon skeemaan. Pierre Bourdieun habitus-teoriaan nojaten 


\section{ESIMODERNIN YKSILÖN RAKENTUMINEN SUOMALAISESSA TAIKAPERINTEESSÄ}

Stark toteaa, että vanhemman sukupolven perinteellinen skeema ei enää ollut tarkoituksenmukainen modernisoituvassa Suomessa, ja siksi vanhemmat ihmiset menettivät toimintakelpoisuuttaan uudessa yhteiskunnassa ja nuoret vastaavasti luopuivat vanhoista tavoista. Taikuus ei enää antanut lisäpisteitä sosiaalisessa kilpailussa, ja nuoret suuntautuivat muihin, hyödyllisempiin strategioihin. Vanha ajattelumalli, joka keskittyi yksilön toimintakelpoisuuteen, oli myös jatkossa yksilöllisyyden rakentumisen keskiössä, mutta keinot kilpailukyvyn parantamiseen muuttuivat. Tämä ulottuvuus ei saa ansaitsemaansa huomiota tässä kirjassa. Toivon, että kirjoittaja palaa tähän aiheeseen myöhemmin. Erot modernin ja esimodernin subjektin välillä tulevat esiin monin paikoin Starkin tekstissä, ja toivon, että hän saa tilaisuuden kehittää ajatuksiaan edelleen myös tästä asiasta, koska tähänastiset johtopäätökset ovat kiehtovia ja erittäin lupaavia. Mielestäni The Magical Self on ehdottomasti perusteellinen ja luova tutkimus esimodernin subjektin yksilöllisyydestä ja muodostaa erinomaisen pohjan tuleviin tutkimuksiin.

\section{KirjallisuUs}

STARK-AROLA, LAURA 1998: Magic, Body and Social Order. The Construction of Gender Through Women's Private Rituals in Traditional Finland. Studia Fennica Folkloristica 5. Helsinki: Finnish Literature Society.

STARK, LAURA 2002: Peasants, Pilgrims, and Sacred Promises. Ritual and the Supernatural in Orthodox Karelian Folk Religion. Studia Fennica Folkloristica 11. Helsinki: Finnish Literature Society.

Fil. tri Camilla Asplund Ingemark toimii akatemiatutkijana Åbo Akademin folkloristiikan laitoksessa. 